\title{
Church breakaways as a prototype of commercialisation and commodification of religion in the Pentecostal Church Movement in South Africa: considering curricula offerings for pastors
}

\author{
Madipoane Masenya \\ University of South Africa, Pretoria \\ masenmj@unisa.ac.za \\ Malesela Masenya \\ University of South Africa, Pretoria \\ masenmj2@unisa.ac.za
}

\begin{abstract}
The common occurrence of church breakaways witnessed in the Pentecostal Church Movement in South Africa today highlights trends that appear bent towards the commercialisation and commodification of religion. Material and financial gain are seen as motivators of such a trend. On the other hand, research shows that signs of underperformance and a poor show in church leadership among religious leaders may be attributed to among others, deficiencies in the initial training of pastors. This article will, through the employment of literature review and careful observation made among communities, discuss breakaway trends and their impact on churches and society. Thereafter, we will suggest pointers to be followed in curriculum development for religious leaders. The article will also briefly refer to the current debate on the decolonisation of curricula offerings in training programmes for pastors. Such an approach could add value to good practice to those who aspire to become religious leaders in serving communities.
\end{abstract}

Key words

Church breakaways; Pentecostal Church Movement; commercialisation; commodification; training of pastors and curricula matters

\section{Introduction and background}

In South Africa there is an ongoing trend in Pentecostal churches whereby young male pastors leave their 'mother churches' to form independent 
churches. These breakaways usually take place when breakaway leaders claim a disquiet with the spiritual tenets, policies and traditions of the mother church. Although many breakaway pastors hide behind spirituality as their reason for leaving, there is a strong belief in communities that such moves are motivated by material and financial gains which these pastors would enjoy after the breakaway. Additionally, there is a belief that they break away so that they would also have the liberty to operate on their own without any strict supervision from an overseeing body, like a church governing structure. The fact that many so-called independent churches enjoy a lot of financial gains is attested to in a report by the Commission for the Promotion of the rights of Cultural, Religious and Linguistic Communities (henceforth referred to as "the Commission") on the commercialisation of religion (Mapumulo 2017). The report reveals that:

Not only were church leaders charging congregants a "consultation fee" before giving them blessings or praying for them, but they were also running fully operational shops where holy water, oil, and clothing were sold to congregants at marked-up prices.

In the same report, there is information that some of the pastors are so brazen as to install ATMs and speed point machines on their premises in a bid to encourage congregants to use them, as a convenient way to give offerings and tithes to the organisation. This report shows that leaders of breakaway groups enjoy many financial and material benefits and such a lifestyle becomes attractive to many upcoming pastors.

Based on the findings of the said report and the public outcry against manipulative churches, this article investigates the impact of breakaway churches in the Pentecostal Church Movement and other church formations in South Africa. The article will be outlined as follows: (1) introduction and background to the discussion; (2) the manifestation of commercialisation and commodification of religion; (3) a reflection on church breakaways in the Pentecostal Movement of South Africa; (4) considering curricula matters to obviate church breakaways. This section will also include the exploration of philosophical grounding in curriculum development that should set parameters in the design of any curriculum. In addition, pertinent pointers from the traditional, constructivist and postmodern curriculum theories will be highlighted for possible adaptation and/or adoption in the training of pastors to enable them to be leaders of note 
in the communities they serve. A short description on the current debate about the decolonisation of curricula offerings, will also be given. The last section (5), will suggest a curriculum model for ministerial formation.

We will refer to relevant literature and use careful observation ${ }^{1}$ of happenings in communities around these issues and the public's opinion to elucidate the phenomenon under discussion. It is our hope that an input of this nature will help to counter leadership styles that are solely motivated by financial gain as these are causing rifts and splits in church organisations and are also destabilising communities in the process. Churches play a crucial role in community building and as such they should be protected from 'fly by night' pastors who are there purely for financial and material gains.

\section{The manifestation of the commercialisation and commodification of religion}

\subsection{The concept, commercialisation}

The dictionary defines the term "commercialisation" as the process by which a new product or service is introduced into a general market (making it available on the market) (www.dictionary.com). In other words, a product enters the market to be sold to consumers. In the context of the current discussion on the commercialisation of religion, this means that services provided to members by a church body have a price tag, overtly or covertly. In explaining this concept, Gitonga (2011, cited in Resane 2018) says that commercialisation of the Gospel is the presentation of the Biblical message either as a commodity for sale for material gain or as an object of investment for personal aggrandisement. The author further refers to the sale of spiritual benefits, such as spiritual healing and offer of prayers for special needs. The latter refers to the donation of money or item(s) to the Church with an expectation that God will repay much more in return.

1 The fact that one of the authors sits in the District Presbytery of one of the South African Pentecostal churches enables not only smooth interactions with members at the clergy level, but also affords an opportunity to observe first-hand what happens within the Movement. Also, the fact that both authors are organic intellectuals within the said community, enables easy access to what happens in the context of the breakaway churches. 
In churches where religion is commercialised, there is emphasis on tithing, seed money, free-will giving, blessing the pastor, selling of various spiritual items that have healing powers etc. In Africa where poverty and sickness are rife, many people easily fall prey to this commercial movement.

\subsection{The concept, commodification}

The term commodification is defined as treating something that cannot be owned or that everyone has a right to, like a product that can be bought or sold (www.dictionary.com). The term also refers to the transformation of goods, services, ideas and not least people into commodities or objects of trade. Additionally, commodification refers to "anything intended for exchange" or "any object for economic value." (www.dictionary.com).

Based on the above definitions, commodification of the church means turning church services into money-making activities where congregants have to pay money in order to receive healing or gain favour from God. Tolofari (2008) researched on the commercialisation and commodification of education. When one applies his findings to religion, it points to the fact that an entrepreneurial approach to the management of a denomination as a user-pays system with an obvious profit motive in the provision of its services to its members is followed. McQuilkin (1988, cited in Resane 2018) refers to this as the unscrupulous methods of gaining funds through common deception, 'bait and switch', psychological manipulation and/ or asking money in exchange of any item that may bring charm, luck or success of any sort. In some instances, church members have to buy church products in order to receive God's blessings. In his article on the commercialisation of theological education, Resane (2017) shows that the main characteristic of a commercialised group is that of a "celebrity cult" where members elevate the leader to some high status of beauty, achievement, prestige and power. Shupe, Stacey and Darnell (2000, cited in Resane 2017) also confirm that possessions like vehicles, clothing and buildings represent the success that congregants yearn to possess and they put the leader on a pedestal of "a divine being whose will is that of God and whose actions are above reproach". Members therefore are deceived to believe that the more the money they pay, the more blessings they will receive from God in return. Prosperity gospel teachings normally abound in such settings and congregates are told to give generously in order to prosper like the leader. 
The new breakaway churches are characterised by marketing and selling of spiritual products such as holy water, church attire, disc holders, utensils, pens and pencils that are said to have healing powers and/or that they bestow special blessings on congregates when they use then in their day to day interactions. Ordinary items like pens, cushions, etc. are prayed for by the leader to give the membership 'blessings' in their daily endeavours. The Commission found that T-shirts, towels and Vaseline were sold to congregants for good luck, meaning that congregants were made to believe that if they bought these items, they would have good luck. (Mapumulo 2017).

In other words, leaders of independent churches know how to use people's needs against them by promising to meet their needs of unemployment, love and luck in their lives. The unfortunate thing is, if miracles do not take place as promised, the faith of the follower is questioned and they have to give more in order to have their needs met. What is happening in these churches, has raised the concern of the public, some religious bodies, the media and government. In 2018, the eNCA Television Channel held a discussion on the commercialisation of churches and the majority of the general public and studio guests were of the view that some churches, especially the independent movements, are prone to commercialisation. Additionally, a survey that was carried out by the channel showed that out of 1313 votes, 92\% answered "Absolutely" and 8\% "Not at all". These results prove that the general public is of the view that churches are being commercialised. To further show that the public has a negative perception regarding the matter under discussion, the following statement by the television comedian, Trevor Noah (2018), went viral on social media on and around $20^{\text {th }}$ March 2018. He said:

Instead of feeding the 5000 hungry people like Jesus did, today's prophets are being fed by the 5000 hungry people.

This statement defines what is happening in new Pentecostal churches where pastors take from the people and live luxurious lives, giving little or nothing to the people. From the foregoing discussion, it can be safely said that religion is being turned into a commodity in South Africa and the motive is money and/or material gain. 
The following section focuses on breakaway churches in the Pentecostal Church Movement and the aim is to establish if some leaders in these the churches are commercialising religion.

\section{A reflection on church breakaways in the Pentecostal Movement}

The fact that Christianity is showing a rapid growth especially in Africa, South of the Sahara, has been well documented by scholars. This rapid growth is characterised by mushrooming Neo-Pentecostal and Charismatic Churches (NPC) ${ }^{2}$ that have become a cause of concern to the public, government and the mainline churches. With regard to the mainline and historical Pentecostal churches, their concern is that they are losing members to the newly formed church formations as these are seducing their members with teachings about prosperity. Mwaura (2001) explains:

It is not only the AIC's that are losing members to the NPC's. Even mainline churches are losing their followers to these new formations and it has challenged them to adjust their forms of worship in line with the charismatic models in order to retain their membership (2001:5).

It seems that, in some cases the liturgy of the mainline church is changed to accommodate the style of worship which is followed in some of the NPC's. This raises questions about the authenticity of the gospel that is taught by these churches that are changing with the wind. The following example can serve as a case in point: At a Roman Catholic Consultation

2 There are differences of opinion among scholars about the use of the terms, "NeoPentecostal churches" and "Charismatic churches". Some scholars (cf. Mwaura) regard them as referring to the same thing, while others view Neo-Pentecostal and Charismatic churches as those churches that have originally been part of mainstream/ mainline Christianity but broke away and still adopt some of the basic tenets of the historical Pentecostal churches (cf. Madany et al 2018). For example, they share with the mainstream churches, the important role of the baptism of the Holy Spirit in the life of a believer as well as the believer's personal experience with Jesus Christ. Charismatic Christianity in addition, stresses spiritual gifts (cf. charismata) as well as miracles as being part of the believer's daily life. The category of breakaway churches discussed in this article is unique because they have actually broken away not from traditional mainline churches, but from mainstream Pentecostal churches as their founders, because they are dissatisfied with how the mother churches operate among others, in terms of the functioning of the work of the Holy Spirit. 
that one of the authors attended in Kumasi, Ghana, in 2002, the church introduced a charismatic sector as a response to the challenge brought by the growth of the NPC's. From this vantage point, it seems the focus among these churches is now on keeping members and not teaching the authentic gospel. In the light of the discussion above, the following paragraphs focus on the formation of breakaway churches in the Pentecostal Movement, the whys and how.

\section{Five characteristics of breakaway formations in the Pentecostal Movement}

In this subsection, our focus will be on formations as they would have been "birthed" by the younger men's moves of breaking away from the historical Pentecostal churches in South Africa ${ }^{3}$.

The five states about breakaway groups show that resignation from the traditional Pentecostal churches normally lead to the formation of independent churches by the breakaway pastor. The Commission for Rights of Cultural, Religious and Linguistic Communities explains further that it is pretty easy for any pastor to start his or her own church:

In the charismatic sector, you start up and report to no one, you report to heaven. If I have a calling tonight, by tomorrow I can buy a tent and a sound system, I can call myself bishop, a prophet, whatever - and I'm good to go ... it can't be like that when you have access to vulnerable people (cf. Sally and Badenhorst 2015).

The following characteristics may be observed in some of the traditional Pentecostal churches and they are usually topics of discussion during meetings in these churches.

\subsection{Encounter with miracle pastors}

At face value, the main cause of the break appears to be the departing minister's dissatisfaction with the church's doctrine, especially as it pertains to the gifts of healing and performing of miracles, among

3 Within the preceding category of churches, we have identified the following: The Full Gospel Church of God; the Assemblies of God Church in South Africa, Apostolic Faith Mission, and the International Assemblies of God Church in South Africa. 
others. However, it is common for such pastors to have had encounters with other pastors (read: "Men of God") who are believed to be miracle workers. Such encounters apparently do not leave the breakaway ministers untouched leading to what may be deemed the commercialisation and commodification of the gift(s) of healing and miracles characterised by the purchase of certain spiritual items, such as holy oil, water, handkerchiefs, pens and pencils, et cetera).

\subsection{Complete autonomy}

The leader of the breakaway group becomes an 'absolute monarch' who acts as the CEO and COO of the new grouping and accounts to none but God. In that manner, his decisions are final as he is normally perceived as the only link between God and his followers. It is generally believed that God speaks to the leader directly and therefore his leadership and decisions cannot be questioned. Questioning such a leader amounts to questioning God himself. The manner in which the leader gives direction to the group becomes law because the leader may not be questioned as a vision bearer.

\subsection{Recruiting members from the mother church}

Members of the 'host' denomination are recruited to follow the splinter group albeit, sometimes in a subtle way. This may be evident in the sermons that mainly criticise the status quo just before the split. The leadership of the denomination is often overlooked or side-lined. These members make great efforts to advertise and publicise the 'new grouping' that is portrayed as occupying an advanced spiritual level compared to their original 'home'. The previous traditions are often looked down upon and vilified. This is done to convince members that their lot is better in the new organisation than what they are used to, in the old setting.

\subsection{Nepotism in the leadership structure}

Family members, especially the spouse and children of the splinter group leader become close associates who help the leader to run the organisation and are usually in control of the church finances. The leader determines his pay and the use of his organisation's resources, and unfortunately in many countries churches are not taxed which means the leaders receive millions of tax-free money. 


\subsection{Prosperity teaching}

Members are urged to give generously to the new establishment with the assurance that giving to this new splinter group is the way to receive blessings and an abundant life from God. The measure of one's blessings is determined by the amount offered to the church; the more the offering the greater the blessing.

\subsection{Young and flamboyant pastors}

The pastors involved are usually younger male pastors who might have received their training from a seminary attached to the mother church or from a different church tradition, albeit with Pentecostal roots.

The above characteristics are similar to those highlighted by the Commission and elsewhere in this article. They indicate that a breakaway group is established to advance the financial standing of its leader and his family.

Taking to consideration the discussion above, we would like to establish if there are ways to circumvent church breakaways and the abuse of religion as their existence causes untold suffering among congregants and the community at large. An example, the rape and human trafficking case that is currently in the South African courts and the so-called "Gabola Church" which encourages its members to hold worship services while under the influence of alcohol and other substances left the South African society puzzled. We are of the view that some of the problems that persist in churches, including breakaways, may be as a result of the poor training of pastors or the absence thereof. The next section discusses problems that exist in pastoral training and advances proposals of how the training of pastors could be approached.

\section{Considering curricula matters as a measure to obviate church breakaways}

The Commission for Rights of Cultural, Religious and Linguistic Communities advanced ways to counter this phenomenon of the commercialisation of religion: proper regulation in the registration of churches, vetting of religious leaders by peers in their profession and promoting awareness among members, are a few suggested procedures in 
this regard (Mapumulo 2017). This means that laws have to be established that govern how churches are registered and by whom and that leaders should be recommended by their peers. This move can help to prevent the abuse of religion by some pastors.

It is however important to state that the Commission is faced with opposition from leaders who benefit from groupings of this nature. The Commission has not had much impact because of underfunding, which makes its work difficult or next to impossible in trying to correct the situation. Legislative red tape is a nother obstacle in this fight.

It is with these facts in mind that this article proposes the training of pastoral candidates as an intervention measure. This recommendation is made in line with the results of a study that was conducted in the past that found that the poor and inadequate training of pastors in their ministry formation concerns many and is seen as having a direct influence on their below par performance once they have graduated from their training institutions (Masenya 2014). This means that pastors who are ill prepared for their practice are easy targets and can easily be swayed into getting involved in destructive activities like recruiting church members to leave the mother church to join new formations.

The following paragraphs will probe inadequate training of pastoral candidates during their pre-service preparation as a possible cause for pastors to pursue the path of breakaways. As indicated in the preceding paragraph, there may be other ways to grapple with this problem though. The following short discussion cannot be regarded as exhaustive and should therefore be seen as a small contribution to a problem facing the community now.

When tendencies of breaking away from one's bona fide church appear, some researchers attribute that to inadequate formal training that produces error in judgement. As early as in the sixties, researchers on church leadership like Reid $(1969: 18,21)$ highlighted that pastor trainees who are not properly trained are bound to fail in their leadership quest.

Bedard (2008:12) supports the same view in the following words:

With heads filled with biblical and theological knowledge, many graduates are found empty-handed in such practical areas such as 
volunteer recruitment and retention, competent handlings of church finances, strategic planning, time management, church marketing, staff relations and policies and procedures for chairing sound parliamentary church business meetings.

Above quote also alludes to serious gaps in the training tenure of pastors. It can thus be concluded based on this argument, that lack of proper training is a possible threat to stability in church organisations which may also lead to splits if pastoral graduates lack an in-depth understanding of what their sphere of operation entails.

In the same vein, Grieg cited by Woodruff (2004:4-5) echoed the words of the Murdock Review Program Officer, John Woodyard, as follows:

Seminaries ... give their graduates skills to study the Bible and theology but not skills to lead the modern church ... Professors often view pastors and the church as "anti-intellectual."

This quotation adds to the view expressed by Bedard and others that the poor training of pastors may have negative implications on the service they provide to communities.

Nürnberger (2002:76) explains the urgency with which he believes the business of training pastors today should be addressed and not treated as a "pastime". He says pastors have more serious problems to worry about than petty doctrinal differences that are geared to benefit individuals. Such critical challenges facing our communities today include discrepancies in life choices, unemployment, corruption, crime and the mushrooming of informal settlements all over the urban areas. The HIV and AIDS epidemic produces untold suffering among the uncared-for orphans. He further warns that the new democracy in South Africa can still explode into chaos and anarchy, should the churches fail to train effective and efficient leaders equal to their task.

Based on this argument, it can be argued that inadequate training may be seen as fertile ground for breakaways by pastors who are ill informed and probably overwhelmed by circumstances alluded to above that they are left with only one option, breaking away from the mother church. If these pastors concerned themselves with the struggles of the communities that their churches serve, there would hopefully be little room for wandering 
and engaging themselves with actions that are detrimental to the welfare of communities.

Omulokoli (2002:60) adds his voice on the need for proper training of pastors as follows:

As we enter the $21^{\text {st }}$ Century, the need for highly trained leaders for the Church in Africa is as acute as ever. The deteriorating situation in Africa - wars, refugees, AIDS, growing levels of poverty and corruption among others - calls for thoroughly trained Christian leaders who will offer to show the way forward through this apparent hopelessness to one of life and hope for all our people.

Good training produces church leaders who will busy themselves with solving societal challenges rather than concentrating on matters of selfadvancement. Such a scenario will probably give little room for the leaders in question to even think or embark on disrupting the main thrust of the church, that is, to better the lives of congregants spiritually and otherwise. The lures of money and fame should not be in the equation when pastors are trained properly and committed to their calling. Phiri \& Werner (2013) also stress the importance of churches in playing a crucial role in the African continent by indicating that a denomination in a particular community might be the only hope for that particular community in addressing important facets of life such as politics and playing an oversight role. They say:

Theological education in its varied forms is absolutely vital not only for the future of African Christianity and for future African church leaders, but also for the social and political witness of Christian churches in African nations and for informed political and prophetic witness in civil society. This is because often Christian churches are a major, or the only partner in civil society in the African continent (2013:xxviii).

The above assertion shows that the teaching and training of pastors should not be treated in a casual manner, but with all the seriousness that it deserves. With such an approach, trained pastors may just be prone to worry more about the ills of society than lining their pockets with money by owning and selling religion to their unsuspecting followers. 
The former Secretary of the United Nations, Kofi Annan (2013:1) on a keynote address at the $11^{\text {th }}$ Tutu lecture in Cape Town, said the following:

There is a crucial role here for Africa's religious leaders in promoting tolerance and understanding of our common humanity. We need them, at every opportunity, to denounce violence, and discrimination, including on the grounds of sexuality. Perhaps above all, they must welcome and safeguard the freedoms of all faiths, not just their own.

In the statement above, Annan emphasises the importance of well-grounded and well-rounded religious leaders who are able to advance the welfare of communities and this refers to pastors in particular. He also stressed the need for tolerance and good leadership displayed by spiritual leaders. This is mentioned in the context of a world ravaged by terrorism, corrupt leaders, political in-fights, poverty and intolerance. To have leaders of this calibre, institutions tasked with the training of pastors should embark on proper training to produce them. Annan said such leaders are a rare breed and communities need them to prosper.

In the light of the above discussion, we purport that proper training is crucial in the performance of pastors and perhaps in curbing the uncalled for splits and breakaways that reduce religion to a commodity to be sold contrary to it being free for all and for advancing communities. It is therefore incumbent upon institutions engaged in pastoral training to design programmes that will help produce well-trained graduates to counter below par training, to improve leadership in churches and to advance communities. In the words of Woodruff (2004:1), the work of a pastor is a challenging one and the tasks are varied. Should the pastor be ill prepared for these tasks, falling by the sideway might mean a breakaway:

Pastors are called upon regularly to preach, visit, counsel, console, and provide spiritual leadership. Pastors are also expected to set the vision for the church, develop the strategy, communicate clearly the purpose and direction of the local congregation, manage and lead change, build and maintain the team of lay leaders, and shepherd people in the church including the ministry staff. He is called on to accomplish this while balancing his spiritual relationship with God and maintaining healthy relationships with his family. The 
expectation of success in each of these areas by the pastor, the congregation, or his family is unrealistic for most ministers.

It is therefore important for pastors to be well-trained and well-prepared for their duties in the church and society. We will now discuss a few insights regarding curriculum matters which may add value when the training of pastors is under review.

\section{Curriculum development}

The aim of this section is to further debate on the training of pastors for ministry and to afford any organisation involved in curriculum development an opportunity to consider these points; thus, the usage of the subtitle "to whom it may concern" in the following subsection. This discussion is even important following the recent call by the South African government to training institutions to discontinue curricula offerings developed in other countries and to advocate the accreditation of the South African based curricula offerings. That being the case, this section highlights pointers in curriculum development that should be considered in the design of curricula for pastors, with the hope that implementing them will produce quality pastoral graduates who are geared to advancing the aspirations of communities rather than their own.

\subsection{To whom it may concern: curricula pointers in the development of pastors}

In the past, prospective pastors were enrolled for training based solely on their confession of faith in God as well as an indication to follow a call in serving God as ministers. Such an approach may suggest, "formal education is not considered essential" (Resane 2017). Religious institutions have, with the passage of time, moved away from this stance and the formal training of those who desire to follow ministry is today taken for granted. In that regard, recent studies show that the formal training of pastors is of cardinal importance by church traditions like the Pentecostal Movement as well as other church traditions in South Africa (Masenya op. cit:116). This article argues that taking matters of curricula seriously in the training of pastors may go a long way in arresting the imagination of trainees, enabling them to amplify their responsibilities towards the community and discouraging 
them from breakaway tendencies. That being the case, a question of what should be included in these training programmes immediately comes to the fore.

The following aspects are seen as forming the basis in any venture of curriculum development and therefore important in planning programmes for pastoral training. We hope that a discussion of these aspects will shed light on matters of curriculum development in general and the training of pastors in particular: (1) Philosophical grounding in curriculum development and (2) Theories of curriculum development. These are discussed below.

\subsection{Philosophical grounding in curriculum development}

Theorists in curriculum development regard philosophical grounding as of great importance in designing the kind of curriculum that is meant to meet the needs it was designed for, to the extent that it reflects personal beliefs and societal ways (Orstein, Pajak and Orstein 2015:1). The expression philosophical training is derived from the noun 'philosophy' which implies a description, explanation and evaluation of the world as seen from the perspective, or through what some social scientists call "social lenses" (Orstein 2015:3). Fundamental beliefs and what is regarded as truth by a community will determine the kind of curricula the community designs for schools and other institutions of learning. This is so because the philosophy of a particular community or group of people or organisation should largely determine the group's decisions, choices and alternatives in educating its members.

Philosophical grounding implies taking cognisance of the needs and aspirations of a particular community and being responsive to them. It thus provides educators and curriculum specialists with a framework of organising schools and classrooms (Orstein op cit: 2). It is important to consider what communities regard as important, that is the very basic tenets of their beliefs and aspirations in curriculum development.

From the above discussion and review of literature in general on this aspect, the following can be presented as a theoretical framework in curriculum development: 
1. Relevance - curriculum designers should strive for relevance whereby only relevant information should be included.

2. Currency - curricula should be revisited regularly and revised to see if they are still addressing the needs of the students and the community they serve.

3. Theoretical underpinning - any consideration to review or change the content of courses offered at any given time in a learning environment, should be undergirded by a sound theoretical framework/paradigm within which this change takes place.

These variables should serve as a guide in curriculum development.

\subsection{Theories of curriculum development}

The traditional, constructivist and postmodern curriculum development theories are discussed in detail elsewhere (Masenya op. cit: 70ff). We will thus mention a few important pointers gleaned from these theories in this article:

- A curriculum is never neutral because learning programmes should be inspired by a world and life view representing the beliefs, aspirations and values of a particular community. Curriculum reform therefore must mirror the community for which it is designed.

- Learning programmes should be open to new ideas and be directed toward social change, community empowerment, and the liberation of the mind, body and spirit of each human being. Following an uncritical master plan for curriculum development should be avoided.

- There are as many perspectives to curriculum development as there are theorists and these perspectives must co-exist. Therefore, society has become a global plurality of competing sub-cultures and movements where no one ideology and episteme (understanding of knowledge) dominate; therefore, there are no absolutes in curriculum development.

- Knowledge is partial, evolving and always in a state of flux, deviant and outside the norm; we must therefore move from structural barriers and stereotypes. 
- A reconceptualised curriculum suggests that education must address pertinent issues (economical, ecological, social, health, and theological) in society.

Ideas such as the above on curriculum planning should stand any pastor trainee in good stead in preparing him/her for future positions in the community with the hope that proper training will be a deterrent factor from breakaway tendencies. The following section presents the views of other scholars who wrote specifically on curriculum issues relating to the forming of pastoral candidates at theological institutions and universities.

\subsection{Inputs by other scholars on theological curricula}

The views of the following scholars cited in Le Marquand and Galgalo (2004) will be followed by a brief statement of how these thoughts could affect curriculum development and the development of programmes in the training of pastors.

Joseph D Galgalo discusses the challenge of adopting Western theological models in curriculum development and suggests the rewriting of curricula. He states that:

Teaching of theology in Africa continues to be a perpetuation of western theological models. The biggest problem is the hermeneutical gap - a gulf between orthodoxy and orthopraxis and a problem to integrate doctrines into the thought system of the African recipients.

This is all the more reason for us to consider the rewriting of curricula, the review of our theological methods and the way we teach theology in Africa to be urgent tasks. It is of little comfort to possess the necessary theoretical knowledge regarding sound doctrine when such knowledge cannot be brought to bear on our worship, life and faith, and everyday living.

This author stresses relevance in matters of training and his views tie up with what was mentioned under theories of curriculum development. In this article, we are of the view that relevant curriculum leads to better performance and motivation by the trainee pastors. It is also likely to encourage them to stay put in their work to address pertinent issues in communities. 
Nyambura J Njoroge is of the view that the challenges experienced by community members should be considered when a curriculum is drawn up. She said:

The curriculum should begin by exploring the causes of pain and suffering in the lives of our people and seek to identify what has brought fullness of life to people in the midst of destruction and death.

Paulo Freire addresses suffering and encourages communities to self-critic:

The curriculum should take seriously the "pedagogy of the oppressed" and the "education for a critical consciousness."

Emphasis here is on the importance of dealing with real life problems and addressing serious issues like poverty.

Musa W Dube expresses a passionate concern regarding the untold suffering of the HIV and AIDS pandemic affecting communities:

I am begging for a theology that help us ask critical questions about our inactivity of wrongdoing; a theology that will help the child, youth, women in the pew and streets to cultivate a dialogue that will lead to life-giving action in the midst of suffering, misery and death.

Dube advocates purposeful enquiry into issues of great concern to communities like the HIV and AIDS pandemic, that is, important communal problems.

The above arguments add to the current debate of decolonisation of curricula offerings in the training of pastors. It is not the intention of this article to delve deeper in arguments for or against decolonisation of offerings. We conclude by stating that a curriculum should take cognisance of what matters greatly to the community for which it is designed. Ward (2017) observes correctly in this regard that offerings should "hook up to the land, its languages, and its spiritual and material histories."

We support the above stated recommendations and urge that they should be taken to heart when designing programmes for training pastors so as to equip them with knowledge and skills on how to contribute to the advancement of communities. Such pastor leaders will have a heart to 
serve their congregations and will hopefully be deterred from self-serving tendencies like church breakaways.

We will follow the trends of thinking that were raised in this section by laying a broad framework on what should be considered for inclusion in the curriculum of pastoral trainees in the next section.

\section{A suggested curriculum model for ministerial training}

In this article, we support the recommendations made by Bedard (2008:298314) that the expansive and collaborative models should be combined in the training of pastors. In such a model, students follow a multiple of disciplines of study as well as vocational training; thus, ministerial training is coupled with some vocational courses which allow pastors to change occupation should such a need arise. The model also enables colleges to develop strategic partnerships with universities and local congregations universities provide expertise and local churches afford students practical exposure to different fields of study during their training.

Bedard suggests that a three-year model should be followed by colleges involved in training of pastors and it should include:

\section{Theological Education}

Basic training (e.g. Church Traditions and Polity Communicative English and Report Writing, Computer Literacy, etc.)

Compulsory Courses like specialisation (e.g. Health Track, Youth Track, etc.).

\section{Counselling studies}

\section{Leadership and Management}

Electives/Informal training (HIV and AIDS, Gender Studies, Poverty Eradication, Conflict Resolution, Additional African Language, Basic Bookkeeping, Urban and Rural Development Studies, etc.).

Le Marquand and Galgalo (2004) follow a different approach to Bedard. They propose that the following be considered: 
Contextualization of Theology (neo-colonialism and exploitation, dictatorial and oppressive governance, poverty, social inequality and injustice' hunger and diseases - especially HIV and AIDS);

Critical African Theology (South African Black Theology and the African liberation theology, racism, tribalism, oppression, injustice, poverty, etc.)

Pastoral Theology (dysfunctional reality of so many families in Africa: polygamous relations, single-parent homes, absent fathers, sexual abuse, youth and children, etc.)

Other areas (relations between the rich and poor, young and old, leaders and followers, literate and non-literate, ordained and non-ordained, taboos, domestic violence, rights of women and children)

The above information should be seen as a guide only and not as cast in stone.

\section{Tying the knot}

Denominational breakaways are a new phenomenon in the church tradition and they are generally seen as a type of commercialisation and commodification of religion. This article suggests that inadequate and poor training offered to ministerial trainees is among others, the likely cause of this new trend. It is unlikely that a pastor who is well-grounded in training and taking the needs of the community seriously could even think of selfaggrandising moves like causing a split in a denomination. The essay thus advocates proper training for pastors and calls for a curriculum grounded on the philosophy of the community for which it is intended, within a sound theoretical framework. Such an approach presupposes courses or offerings included in the curriculum that are beneficial to and responsive to community needs with little room for self-advancement tendencies.

\section{List of references}

Annan, K 2013. “The way forward for our continent.” Unpublished paper read at the Annual Desmond Tutu International Peace Lecture. Cape Town: University of the Western Cape. 
Back Chat. 2018. TV programme. Discussion about the commercialisation of churches. 16 February 2018. Presenters: Busisiwe Gumede and Sia Leita. Guests: Nomsa Silinda, Walter Mashilo, Nyiko Mgiba and Tiisetso Makhubedu.

Bedard, RL 2008. "Emerging models of ministerial training for

Pentecostal Assemblies of Canada." Unpublished doctoral thesis.

Pretoria: University of South Africa.

Clifford, R 2002. Abingdon Old Testament Commentaries, Psalm1-72.

Nashville: Abingdon Press.

Gerstenberger, ES 2014. Non-Temple Psalms: The Cultic Setting Revisited.

In: The Oxford Handbook of the Psalms, edited by William P. Brown.

Oxford: Oxford University Press. 338-349.

Commercialisation. [Online]. Available: www.dictionary.com/browse/

commercialisation [Accessed: 18 June 2017].

Commodification. [Online]. Available: www.dictionary.com/browse/ commodification [Accessed: 18 June 2017].

Groenewald, A 2015. Psalm 69:33-34 in light of the poor in the Psalter as a whole. Verbum et Ecclesia. Online Journal, OASIS.

Le Marquand, G and Galgalo JD (eds) 2004. Challenges for theological education in the 21st century. (Papers from the Limuru Consultation on Theological Education at St. Paul' United Theological College in Nairobi. Printed in Eldoret, Kenya).

Madany, B et al. 2018. Supplement-Report 34. Study Committee Reports. Neo-Pentecostalism (Arts. 74, 76). 398-493.

Mapumulo, Z 2017. “Commission slates churches' abuse of faithful.” City Press. [Online]. Available: https://www.pressreader.com/south-africa/citypre ss/20170716/281754154369327 [Accessed: 25 October 2018].

Masenya, MJ 2014. "Re-envisioning management training of pastors in the colleges of the International Assemblies of God (IAG) of South Africa." Unpublished doctoral thesis. Pretoria: University of South Africa. 
Mwaura, PN 2005. A spirituality of resistance and hope: African Instituted Churches' response to poverty. Orita Ibadan Journal of Religious Studies. Volume XXXVII, June-December: 65-83.

Noah, T 2018. "Instead of feeding 5000 people." [Online]. Available: https://twitter.com/elirri/status/892284341803507712?lang=bg [Accessed: 29 October 2018].

Nürnberger, K 2002. "Ministerial training for the $21^{\text {st }}$ century: A South African case study." Ministerial Formation. 98-99. JI-O:76-83.

Omulokoli, WAO 2002. "The challenge of leadership training for churches in post-independence Africa." AICMAR017. Bulletin. 1:46-60.

Ornstein, AC 2015. Philosophy as a basis for curriculum decisions. In: Ornstein, AC, Pajak, EF and Ornstein, SB (eds). Contemporary issues in curriculum. Sixth edition. Boston: Pearson.

Phiri, IA \& Werner, D (eds) 2013. Handbook of theological education in Africa. Dorpspruit: Cluster.

Reid, CH 1969. Leadership styles in church administration. Pastoral Psychology. September 1969.

Resane, KT 2017. "Commercialisation of theological education as a challenge in the Neo-Pentecostal Charismatic churches." HTS Teologiese Studies/Theological Studies. 73(3), a4548. Available: https:// doi.org/10.4102/hts.v73i3.4548 [Accessed: 24 October 2018].

Selly, A and Badenhorst, A 2015. "Why we cannot regulate religion (Part 1)." S.n.

Tolofari, SV 2008. "The commodification of higher education in the welfare state of Sweden: exploring the possibilities." Unpublished doctoral thesis. Glasgow: University of Glasgow.

Ward, G 2017. Decolonizing theology. Stellenbosch Theological Journal 3(2): 561-584. Available: http://dx.doi.org/10.17570/stj.2017.v3n2.a26.

Woodruff, TR 2004. "Executive pastor's perceptions of leadership and management competencies needed for local church administration." Unpublished doctoral thesis. Michigan: The Southern Baptist Theological Seminary. 